\title{
Future management options for cembran pine forests close to the alpine timberline
}

\author{
Nathalia Jandl ${ }^{1} \cdot$ Robert Jandl $^{2} \cdot$ Andreas Schindlbacher $^{2}$ \\ Received: 13 December 2017 / Accepted: 14 June 2018 / Published online: 15 August 2018 \\ (c) The Author(s) 2018
}

\begin{abstract}
- Key message High-elevation forests in the Alps protect infrastructure and human lives against natural hazards such as rockfall, flooding, and avalanches. Routinely performed silvicultural interventions maintain the required stand structure but are not commercially viable in remote forests due to high operational costs. Financial subsidies for the management of high-elevation protection forests are an efficient strategy to ensure sustainable forest cover.
\end{abstract}

- Context Presently, many high-elevation forests in the Alps are managed in order to ensure the provision of ecosystem services with emphasis on the minimization of natural hazards.

- Aims We studied the possible economic performance of a high-elevation protection forest from an owner's perspective. We investigated whether the increase in productivity due to climate change and a favorable market for the dominating cembran pine (Pinus cembra L.) are sufficient for profitable timber production in protection forests.

- Methods We simulated the standing timber stock and the soil carbon pool for a 100-year period with climate-sensitive models and compared harvesting costs with expected revenues. Our scenarios included different climates, intensities of timber extractions, parameters of the timber market, and the availability of government subsidies.

- Results Overall, the productivity of forests increases by approximately $15 \%$ until the end of the century. In a zeromanagement scenario, the forest accumulates carbon both in the aboveground biomass and the soil. In the case of an extensive management with moderate timber extractions every 50 years, the carbon stocks decline both in biomass and soil. A more intensive management scenario with extractions every 30 years leads to substantial losses of the soil and biomass carbon pools. In addition, the stand structure changes and the protective function of the forest is not sustainably ensured. Timber production can be economically successful only with high selling prices of cembran pine timber and the availability of governmental subsidies for forest management. The admixed European larch (Larix decidua Mill.) contributes only marginally to the economic success. The main challenge are harvesting costs. The costs of timber extraction by a long-distance cableway logging system exceed the value of the harvested timber.

- Conclusion The intensification of forest management cannot be recommended from the perspective of timber production, sustainable forest management, and protection against natural hazards. Our simulation experiment shows that the extraction of timber at decadal intervals depletes the carbon stock that is insufficiently replenished from aboveground and belowground litterfall. Leaving the forest unmanaged does not impose a particular threat to stand stability and is under the encountered situation, a justified strategy.

Keywords Growth modeling $\cdot$ Soil carbon pool $\cdot$ Climate change $\cdot$ Mountain forest $\cdot$ Forest management costs

Handling Editor: Andreas Bolte

Contributions of the co-authors NJ performed the economical analysis and co-wrote the manuscript. RJ conceived the experiment, participated in field work and data analysis, and co-wrote the manuscript. AS participated in data analyzing and interpretation and co-wrote the manuscript.
This article is part of the topical collection on Forest Adaptation and Restoration under Global Change

Extended author information available on the last page of the article. 


\section{Introduction}

The productivity of mountain forests in the Alps currently increases (Lexer et al. 2015; Bircher et al. 2015). Assuming a warming trend of $3{ }^{\circ} \mathrm{C}$ in the next century and a lapse rate of 0.6 to $0.8{ }^{\circ} \mathrm{C}$ per $100 \mathrm{~m}$ in elevation, climate change would establish thermic conditions that are presently found 375 to $500 \mathrm{~m}$ lower, whereas the nutrient supply from the rocky and acidic soil may be a limiting factor. Forest managers expect a habitat shift of tree species, altered competition patterns within the forests, changes in biotic pressures, and possibly more extreme events (Hanewinkel et al. 2012; Reichstein et al. 2013; Thom et al. 2017). Well-known but unresolved challenges are forest damages due to high population densities of chamois (Rupicapra rubicapra) and red deer (Cervus elaphus) (Frehner et al. 2005; Bundesamt für Umwelt (BAFU) 2010).

Recommendations for adaptive forest management use the concept of close-to-nature-forestry. It intends to increase the stability of the forest structure and minimize the exposure to biotic and abiotic disturbances (Bauhus et al. 2013; Brang et al. 2014; Lexer et al. 2015; Pluess et al. 2016; Trumbore et al. 2015). Such guidance is similar to classical textbook knowledge for protection forests where silvicultural activities that are securing long-term stand stability, structural diversity, and predictable spatial distributions of tree groups in different stages of their development are higher rated than strategies that increase the productivity (Mayer 1976). The intended effect is the distribution of prevalent and emerging risks to different trees in order to ensure a continuous forest cover.

Mountain forests close to the timberline are often of marginal productivity. The protection of settlements and infrastructure by forests against natural hazards such as soil erosion, rock fall, floods, and avalanches is more important than timber production (Mayer 1976; Price et al. 2011). Additional ecosystem functions such as provision of drinking water, biodiversity, carbon sequestration, and scenic beauty are also generated by properly managed mountain forests (Borsdorf and Jandl 2009; Fuhrer et al. 2006; Jandl and Price 2011). In recognition of these forest functions, the Austrian Forest Act (Forest Act 1975) requires forest owners to maintain the protective function via regulation of the stand structures. Necessary, yet economically unviable forest operations are subsidized on a project basis under supervision of the forest authorities. The financial resources are provided by regional, national, and international funding programs with different durations.

For many decades, the political intention has been increasing both the area and the standing biomass stock of mountain forests in order to establish fully functional protection forests. Between 1774 and 1880, the forest cover in Tyrol had been reduced by $50 \%$, as compared to today's values, in order to provide high-elevation pasture land and to satisfy the energy demand of mining, cottage industry, and people. Flooding, land slides, and catastrophic avalanche winters stimulated reforestation activities that were partly financed by the European Recovery Program after World War II (Aulitzky 1963; Turner 1961; Moser and Peterson 1981; Jandl et al. 2012). Until the end of the twentieth century, due to efficient forest stewardship including highly disciplined forest management strategies and the separation of pastures and forests, the deficit in forest coverage had been overcome. The standing tree biomass stock in highelevation forests has reached a high level and is nowadays offering opportunities for timber mobilization (Amt der Tiroler Landesregierung 2011; Tasser et al. 2007).

High-elevation forests are usually harsh environments and few tree species are able to establish stands that sustainably can cope with short growing seasons, low nutrient supply from soils, and extreme weather events. Close to the timberline of the Inner Alps, the native cembran pine is forming stable stands. Its productivity is low, yet the favored properties are its longevity, low mortality, and the formation of a continuous forest cover. The relevance of cembran pine for the Austrian forestry sector is modest, with a share of only $0.5 \%$ of the forest area and standing stock (i.e., $15,000 \mathrm{ha} ; 4,784,000 \mathrm{~m}^{3}$, respectively) and $0.2 \%$ of the annual increment. More than a third of the standing stock is in forests older than 140 years. Approximately $4 \%$ of the Austrian protection forests are dominated by cembran pine. For protection forests at the timberline of the Inner Alps, cembran pine has no alternative. The stands are often under-utilized or not actively managed at all. The annual extraction of cembran pine timber between 1980 and 2000 was $10,000 \mathrm{~m}^{3}$. The exceptionally high extraction of timber between 2000 and 2009 of $30,000 \mathrm{~m}^{3}$ was due to natural mortality and salvaging of damaged timber (Österreichische Waldinventur 2016). A study on beneficial effects of cembran pine wood furniture on human well-being has raised a debate on more active management forms and higher extractions (Grote et al. 2003).

For our study, we chose a well-investigated area in Tyrol, Austria, and modelled forest productivity under two IPCC-climate scenarios. Forest management was reflected by three levels of harvest intensity, commensurate with recommendations of regional forest practitioners. We analyzed the effect of harvesting on the standing biomass stock and on the soil carbon stock in order to identify a sustainable management intensity. Finally, we added an economy analysis in order to test whether the simulated forest management strategies are economically feasible. The results were used to decide whether new concepts of forest management can be recommended. 


\section{Sites and methods}

\subsection{Experimental site}

The investigated cembran pine forest in Obergurgl $\left(46^{\circ} 53^{\prime}\right.$ $\mathrm{N}, 11^{\circ} 3^{\prime} \mathrm{E} ; 2070$ to $2150 \mathrm{~m}$ a.s.l.) is a protection forest that is located on a W-facing slope at the upper limit of the timberline ecotone (Fromme 1961). The hillslope used to be an open range land for a small number of goats and cattle until the early twentieth century. Land use history has created suitable conditions for the development of larch as the subdominant tree. Presently, all forests of the Upper Ötztal are protection forests. The Forest Act obligates the owners to manage the forests in a manner warranting sustainable structural stability (Forest Act 1975). The investigated stand protects the hamlet Poschach and a road that connects the village Obergurgl with the lower parts of the Ötztal valley (Fig. 1). The study site is dominated by cembran pine with a diameter range of 30 to $85 \mathrm{~cm}$ and a height of dominant trees of $18 \mathrm{~m}$. The basal area is approximately $48 \mathrm{~m}^{2} \mathrm{ha}^{-1}$. In spring, the protection forest is routinely inspected by the local forest authorities. The forest owners are informed about tree damages and tree mortality. Even though livestock is contained outside of the
Fig. 1 The area of the study site Obergurgl. The green marker shows the investigated cembran pine stand. The red shades are actively managed protection forests, the light purple shades are unmanaged protection forests, and the dark purple shades are krummholz areas. The inserted photograph shows the cembran pine-dominated forest. Source of the map: https://www.tirol.gv.at/ statistik-budget/tiris/

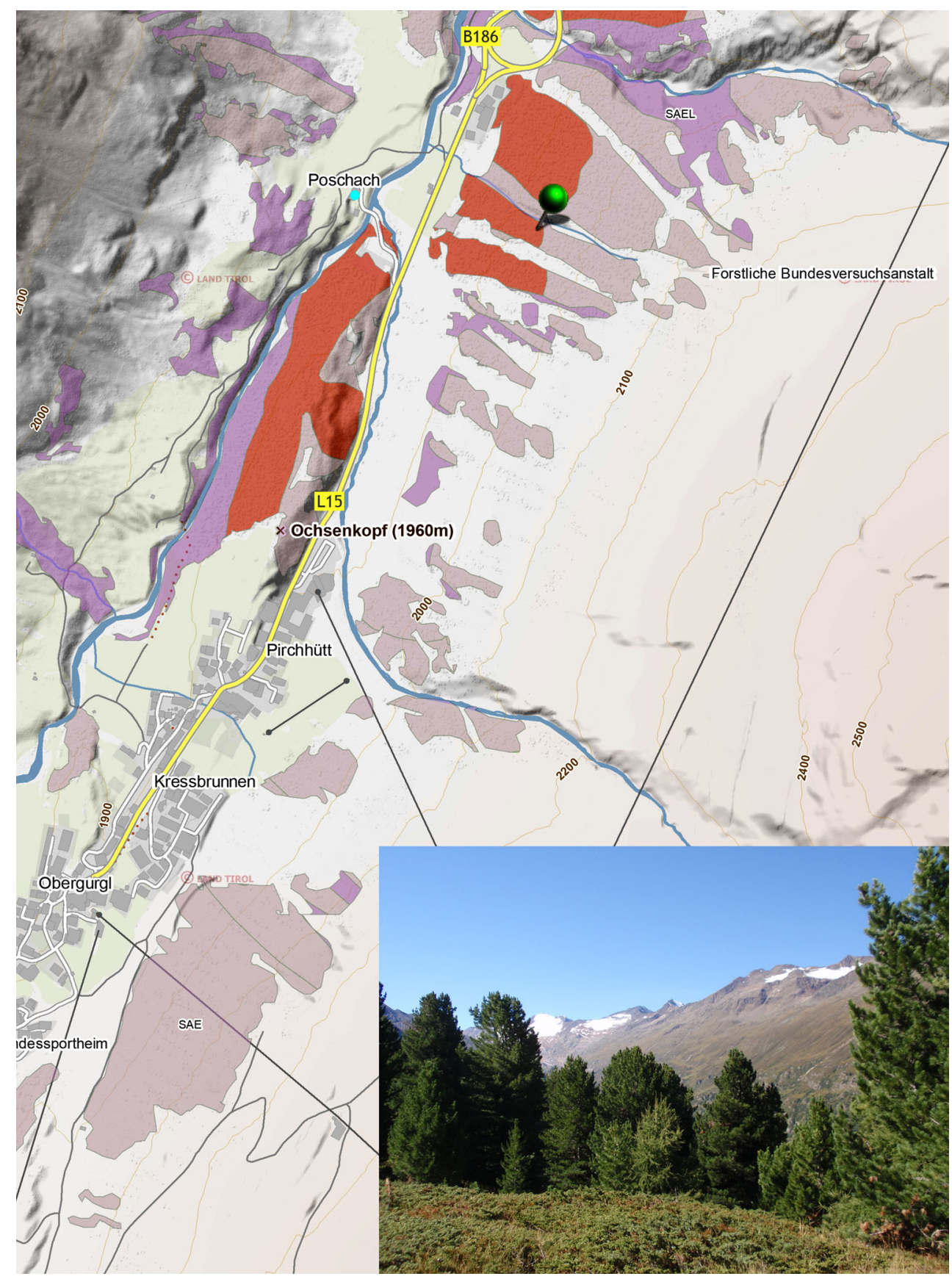


forest, there is evidence for browsing from chamois and red deer. The regulation of an acceptable population density is a long-standing yet unresolved issue between foresters and hunters.

The soils are podsols derived from silicatic bedrock and glacial moraines (IUSS Working Group WRB 2015). At the meteorological station Obergurgl (1927 m a.s.l.), the annual precipitation is $830 \mathrm{~mm}$. We used a regional climate scenario based on the A1B and B1 SRES scenarios of the IPCC, corresponding to RCP4.5 and RCP6, respectively (Nakicenovic and Swart 2000; Zimmermann et al. 2013; Rogelj et al. 2012). The temporal trend of the annual air temperature is shown in Fig. 2. The moderate scenario B1 shows an increase by $3{ }^{\circ} \mathrm{C}$ until the end of the century, whereas A1B even suggests an increase by more than $5^{\circ} \mathrm{C}$. The insert in Fig. 2 shows a warming trend since the early twentieth century. The changes in precipitation are highly uncertain. In the scenarios A1B and B1, we found no clear temporal trend towards moister or drier conditions. Neither scenario showed significant monthly anomalies.

The site is not accessible by forest roads. A long-distance cableway logging system is required to deliver timber to the valley bottom at approximately $1900 \mathrm{~m}$ a.s.l. An estimate in practical forestry calls for $1 \mathrm{~m}^{3}$ harvested stem wood per 1 $\mathrm{m}$ length of the cableway system (Pestal, pers. commun.). Under the given site conditions, the cable line can extend to $650 \mathrm{~m}$. The lateral reach in thinning operations is limited to $20 \mathrm{~m}$ to each side of the line, accessing an area of 2.4 ha. With the strategy of leaving two thirds of stand area intact and sparing vital tree groups from harvesting, the net accessible area for timber extractions reduces to 0.8 ha.

\subsection{Simulating forest growth and the soil organic carbon pool}

Forest growth was simulated with the distance-independent model CÂLDIS. It includes modules for diameter- and height-growth, and handles the competition between trees. CÂLDIS is conceptually based on the productivity model "PrognAus" (Monserud and Sterba 1996). An ingrowth module describes the recruitment of naturally regenerating trees (Ledermann 2002). Both the diameter and height increment modules are climate sensitive. The climate parameters are based on monthly temperature and precipitation data. The species-specific response of different trees to climate parameters is embedded in the model (Kindermann 2010; Ledermann et al. 2017). The output of CÂLDIS is the "diameter at breast height" (dbh) [cm] and the "height" (h) $[\mathrm{m}]$ of individual trees. From these data, the volume and mass of stems were estimated (Ledermann and Neumann 2006; Dolschak et al. 2013). The mass of needles and leaves, branches, and roots was calculated with biomass expansion functions (Eckmüllner 2006; Wirth et al. 2004; Ledermann and Neumann 2006; Helmisaari et al. 2002; Offenthaler and Hochbichler 2006). The representation of the disturbance regime is a particularly challenging aspect of forest growth modeling (Dale et al. 2001;
Fig. 2 Annual mean air temperature in Obergurgl according to the IPCC SRES scenarios A1B and B1. The insert shows the temperature anomaly at meteorological mountain stations compared to the reference period 1960 to 1990

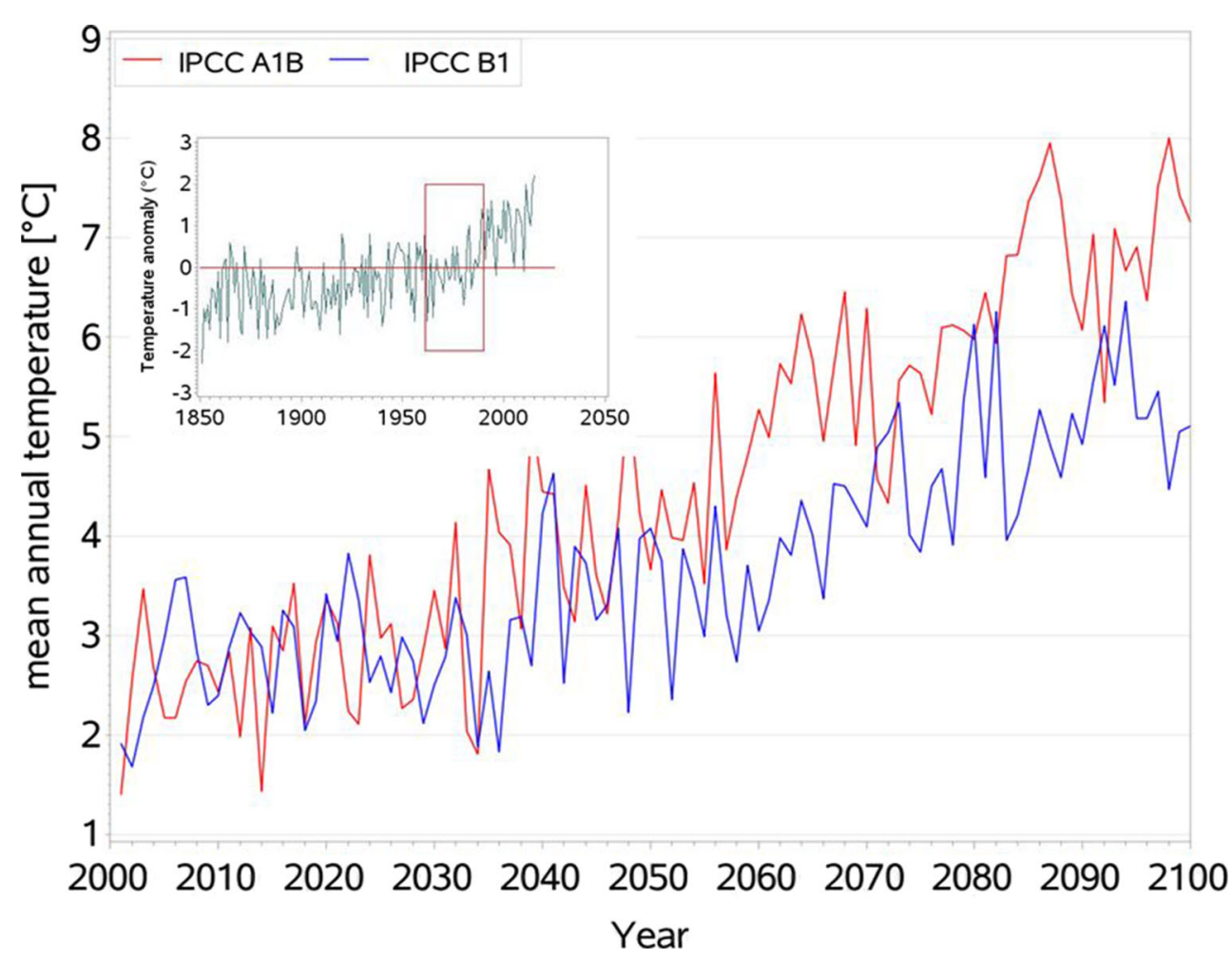


Gardiner et al. 2013; Seidl et al. 2017). The storm-damage module of CÂLDIS is parameterized based on evidence of storm-related damages from the National Forest Inventory and on local wind velocity data (WAMOD 2010). The future pressure from pests and pathogens at the upper timberline is expected to be small. The dominant cembran pine is currently only marginally affected by bark beetles. In general, lowelevation spruce forests are affected to a higher degree by insect damages than pine-larch forests at the timberline (Chinellato et al. 2013; Marini et al. 2012; Netherer et al. 2015).

In our growth simulations, we captured the range of possible forest management strategies. We used three management intensities, where interventions started in the reference year 1960. A requirement of each form of management was the sustainable maintenance of the diverse structure of a protection forest (Mayer 1976). That implied (i) removing not more than $30 \%$ of the standing biomass at any single-harvesting operation, and (ii) extracting trees from the highest diameter class in order to open growing space for regenerating trees. The maximum diameter of cembran pine was above $60 \mathrm{~cm}$ in the first interventions and between 40 and $60 \mathrm{~cm}$ in subsequent thinning. All cembran pines and $50 \%$ of the larches of the largest diameter class were removed at predefined intervals. This scenario implied that dominant members of the cembran pine cohort were removed in order to regenerate the forest. Pragmatically, in each intervention, some larch was extracted in order to maintain the original balance of the tree species composition. In the "zero management" scenario, eventual losses of the standing biomass stock were driven by the competition between trees and natural tree mortality. "Extensive management" implied harvesting at 50-years intervals; "intensive harvesting" implied interventions every 30 years.

The soil carbon model Yasso07 estimates the soil carbon pool of forests, driven by climate parameters, the aboveand belowground influx of carbon to the soil, and the chemical quality of the incoming organic matter (Liski et al. 2009; Tuomi et al. 2008; Rantakari et al. 2012). The output is the total soil organic carbon pool. From the standing stock of individual compartments of the tree biomass, the carbon fluxes into the soil were estimated (Dolschak et al. 2013). Although soil erosion on steep slopes is a common phenomenon, it is not reflected in the soil carbon simulation (Lal and Pimentel 2008).

\subsection{Economic evaluation}

We reduced the simulated stem biomass in order to reflect the regional harvesting practice implying logging residues of approximately $20 \%$. For assigning a timber price, we distinguished three timber quality classes according to the nomenclature of the Austrian timber market, i.e., B/C for valuable
Table 1 Price range of timber for different qualities of cembran pine and larch stems, expressed in $\left[€ \mathrm{~m}^{-3}\right]$; evaluated time span 29.5.200329.5.2014

\begin{tabular}{lll}
\hline Timber quality & Cembran pine & Larch \\
\hline B/C & $145-209$ & $100-111$ \\
C+ & $93-131$ & $61-75$ \\
Fuel wood & $23-35$ & $23-35$ \\
\hline
\end{tabular}

Source for long-term average prices: (Land Tirol 2017)

timber, $\mathrm{C}+$ for low-quality timber, and fuel wood. Based on the information of the local forest authorities, we assigned $40 \%$ of the harvested volume to $\mathrm{B} / \mathrm{C}$ and $\mathrm{C}+$ quality, respectively, and the remaining $20 \%$ to fuel wood. Furthermore, we use for the evaluation both the long-term average timber price and the presently high timber values (Table 1).

The income derived from timber sales can be augmented by a government subsidy of currently $€ 14$ per $\mathrm{m}^{3}$ (Amt Tirol 2017). The harvesting costs include the long-distance cableway logging system of $€ 70-80 \mathrm{~m}^{-3}$ (Österreichisches Kuratorium für Landtechnik 2017), the chain saw costs of $€ 1.25 \mathrm{~m}^{-3}$, and the personnel costs (approx $€ 10$ $\mathrm{h}^{-1}$ ), according to the legally binding "Mantel contract" (Gewerkschaft PRO-GE 2014). The potential revenue from forest management was calculated as the difference between the immediate investment (coverage of costs) and the achievable return by timber sales.

The net present value (NPV) is a method for a costbenefit analysis in situations where the costs and the returns of investment are getting effective at different points in time. The NPV is calculated as

$N P V=\sum_{t_{0}}^{n} \frac{R_{t}-E_{t}}{(1+i)^{t}}$

where $t$.. time (years), $i_{t} \ldots$ interest rate, $R_{t}-E_{t}$ ... difference between return and investment at time $t$. $i$ was chosen with $1.5 \%$ according to Möhring and Püping (2008).

The considered time span was 1960-2099. The calculation of the interest rate does not consider the entire period, but only the years of harvesting, i.e., when a flow of money occurs. In the scheme of harvests in the years 2010 and 2060, the income from the harvest of the year 2010 is accrued to the year 2013, the income of the year 2060 is discounted to the year 2013 .

Data availability The datasets generated during the current study are available in the CCCA Data Centre repository, [PID: https://hdl.handle.net/20.500.11756/0563079a. [April 17, 2018]]. (Jandl et al. 2018). Datasets are not peer-reviewed. 
Fig. 3 Simulated growth rate of the cembran pine forest in Obergurgl for two climate scenarios and three management strategies. The volume is expressed in $\left[\mathrm{m}^{3}\right]$ stem wood per hectare [Vfm]



\section{Results}

Under the climate scenario A1B and zero management, the standing stock of stem wood increased from $\approx 250$ $\mathrm{m}^{3}$ in 1960 to $377 \mathrm{~m}^{3}$ in the year 2100. The stand developed into diameter classes up to $95 \mathrm{~cm}$. The natural regeneration in the existing forest and mortality due to natural disturbances were rare events. Under the climate scenario B1, the productivity remained lower than in climate scenario $\mathrm{A} 1 \mathrm{~B}$, indicating that stand productivity greatly benefits from warming and the elongation of the growing season. "Extensive forest management" with the simulated intensity allows maintaining the standing biomass stock of the forest. The difference in productivity between the two climate scenarios is small in case of extensive forest management. In the "intensive management" strategy, the standing stock quickly declines and can only be recovered when increasingly smaller quantities of timber are extracted (Fig. 3). The amount of extracted timber after deduction of harvesting losses is given in Table 2. In all cases, the harvested timber volume is far below $100 \mathrm{ha}^{-1}$.

The effect of forest management on the total soil carbon pool is highly dependent on the forest management scenario. Zero forest management enables building up a high soil carbon stock. As consequence of harvesting operations, the soil carbon stock is reduced, mainly because less carbon is reaching the soil via above- and belowground litterfall (Tuomi et al. 2009) (Fig. 4). The starting points of the simulations differ slightly for a technical reason. In order to define a steady-state level of the carbon pool at the start of the simulation, the carbon flux into the soil during the entire simulation period was averaged. This initial value was higher in the scenario where all trees are shedding organic matter into the soil than in scenarios where some trees are extracted.

The range of achievable incomes on the timber market and the associated harvesting costs are shown in Table 3. In the extensive forest management, the income is achieved after 50 years, and in the intensive management, the income

Table 2 Harvested biomass in two active management scenarios in units of $\left[\mathrm{m}^{3}\right]$ harvested stem biomass

\begin{tabular}{|c|c|c|c|c|c|c|}
\hline \multirow[b]{2}{*}{ Year } & \multicolumn{3}{|l|}{ Scenario A1B } & \multicolumn{3}{|l|}{ Scenario B1 } \\
\hline & European larch & Cembran pine & Total & European larch & Cembran pine & Total \\
\hline & \multicolumn{6}{|c|}{ Extensive management } \\
\hline 2010 & 8.2 & 41.5 & 49.7 & 7.1 & 61.5 & 68.6 \\
\hline \multirow[t]{2}{*}{2060} & 9.9 & 82.9 & 92.8 & 11.2 & 78.0 & 89.0 \\
\hline & \multicolumn{6}{|c|}{ Intensive management } \\
\hline 1990 & 5.8 & 67.0 & 72.8 & 6.6 & 67.0 & 73.6 \\
\hline 2020 & 10.5 & 67.9 & 78.4 & 10.0 & 73.9 & 83.9 \\
\hline 2050 & 7.7 & 19.3 & 27.0 & 7.4 & 14.2 & 21.6 \\
\hline 2080 & 5.7 & 8.7 & 14.4 & 5.3 & 6.2 & 11.5 \\
\hline
\end{tabular}


Fig. 4 Temporal trend of the total soil carbon pool as simulated with Yasso07 for different intensities of forest management and different climate scenarios

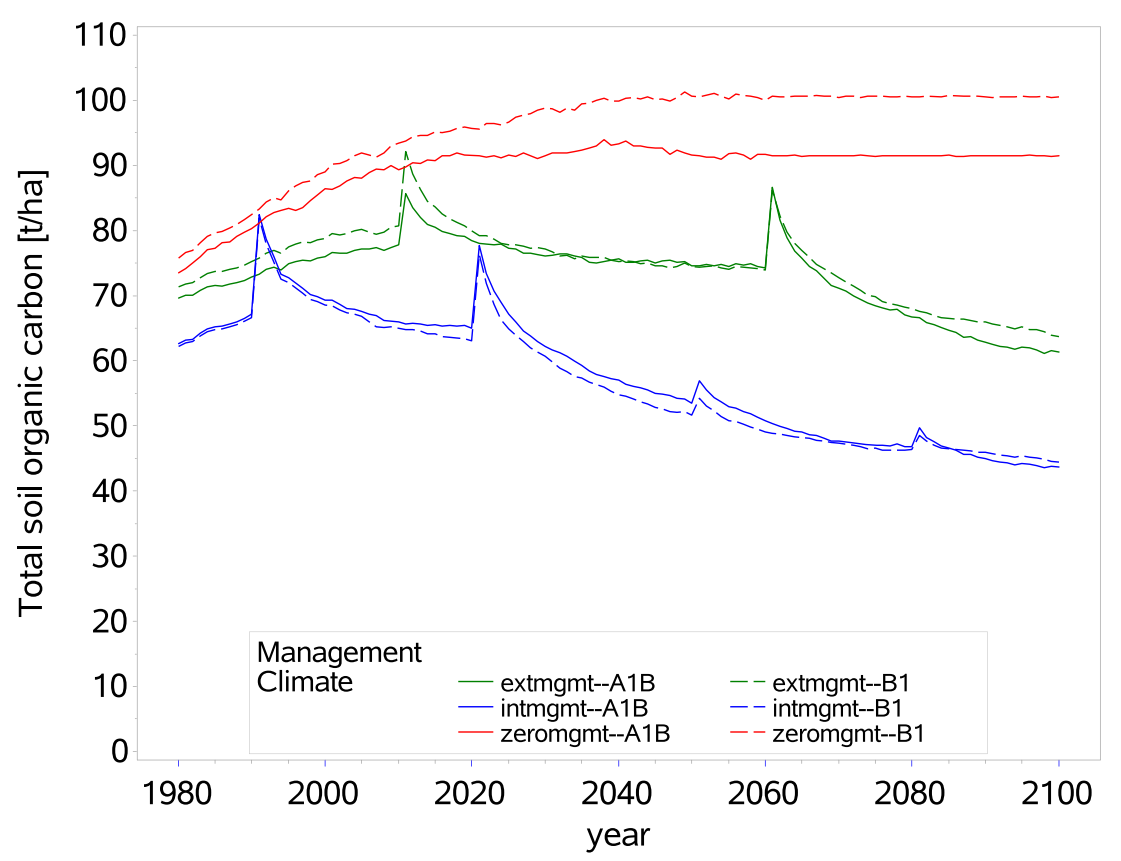

occurs every 30 years, i.e., once per generation of people. The estimates are based on current high and long-term average prices for larch and cembran pine timber according to Table 1 and the availability or unavailability, respectively, of government subsidies. The lowest income is generated at unsubsidized forest operations at average timber prices; high incomes are possible when subsidies are awarded and when the market price for timber is high.

The range of "net present values" for two price levels of timber and the availability and unavailability, respectively, of government subsidies for a reference area of 1 ha is shown in Table 4. Cembran pine has by far the larger contribution to the NPV because it dominates the forest and the timber price is developing far more dynamic, whereas larch contributes little to biomass and revenue.
The revenue for each cubic meter of harvested wood and the rentability of timber production, calculated as the quotient of output and input $(€)$, are between 1.3 and 1.6 for European larch and 2.3 and 2.5 for cembran pine, respectively. The interest rate for the invested money is shown in Table 5. The table gives the range of values for high and low timber prices, respectively, so as the availability or unavailability of government subsidies, and also comprises two climate scenarios.

\section{Discussion}

The forest management options used in our simulations are reflecting the limitations for foresters that are imposed
Table 3 Range of achievable income $[€]$ from the harvested timber and harvesting costs according to the "Mantelvertrag" for two management intensities and two climate scenarios at longterm average and high timber prices and w/o governmental subsidies for the management of protection forests

\begin{tabular}{|c|c|c|c|c|}
\hline \multirow[t]{2}{*}{ Year } & \multicolumn{2}{|l|}{ Scenario A1B } & \multicolumn{2}{|l|}{ Scenario B1 } \\
\hline & $\begin{array}{l}\text { Income } \\
{[€]}\end{array}$ & $\begin{array}{l}\text { Harvesting costs } \\
{[€]}\end{array}$ & $\begin{array}{l}\text { Income } \\
{[€]}\end{array}$ & $\begin{array}{l}\text { Harvesting costs } \\
{[€]}\end{array}$ \\
\hline & \multicolumn{4}{|c|}{ Extensive management } \\
\hline 2010 & $4080-6690$ & 3770 & $5730-9130$ & 2735 \\
\hline \multirow[t]{2}{*}{2060} & $7740-11760$ & 5100 & $7400-12330$ & 4900 \\
\hline & \multicolumn{4}{|c|}{ Intensive management } \\
\hline 1990 & $6120-9770$ & 4050 & $6170-9840$ & 4000 \\
\hline 2020 & $6480-10310$ & 4650 & $6970-11100$ & 4260 \\
\hline 2050 & $2140-3350$ & 1490 & $1680-2620$ & 1190 \\
\hline 2080 & $1100-1700$ & 790 & $860-1320$ & 630 \\
\hline
\end{tabular}


Table 4 Net present value of the revenue from timber production (€) for the period 1960 to 2100 for two climate scenarios and two forest management scenarios, two price levels for timber, and the assumption of existence/not-existence of government subsidies per hectare forest in the study forest in Obergurgl

\begin{tabular}{lll}
\hline Management intensity & $\begin{array}{l}\text { Scenario A1B } \\
{[€]}\end{array}$ & $\begin{array}{l}\text { Scenario B1 } \\
{[€]}\end{array}$ \\
\hline Extensive & $4500-7300$ & $3600-6000$ \\
Intensive & $5470-15,100$ & $3320-12,150$ \\
\hline
\end{tabular}

by natural constraints and forest policy: The productivity of the high-elevation forests in the Alps is low due to short growing seasons and nutrient poor and shallow soils. Nitrogen enrichment of ecosystems is a common phenomenon of the developed world and has already led to a marked increase in growth rates during the last decades (Jandl et al. 2012; Nicolussi and Thurner 2012; Pretzsch et al. 2013; Rössler 2015). A further productivity increase due to warming is underway. In our growth simulation, no single run had suggested a strong effect of disturbances such as storm damages or mortality due to pests and pathogens. The timberline forests are still beyond the reach of biotic risks such as bark beetles. Even under warmer conditions, these insects will likely not be able to establish stable populations due to temperature constraints (Chinellato et al. 2013; Netherer et al. 2015). A threat to forests is the increase in storm damages (Gardiner et al. 2010; Seidl et al. 2017). Fortunately, storms are not critical for forests in deeply incised tributary valleys in the Alps. High wind velocities are recorded on exposed treeless ridges whereas the forests below the ridges are well protected. The low risk supports the concept that cembran pine-dominated forests can be managed in rotation cycles of several hundred years, as long as the wildlife density (red deer, chamois) is kept at low levels and the continuous regeneration of trees in stand gaps is ensured (Frehner et al. 2005; Reimoser 2003; Senn and Schönenberger 2001). In the long run, climate change will lead to a change in the tree species composition with different sets of biotic stressors (Hanewinkel et al. 2012). As a consequence of climate change, the timberline is moving upwards. An occasional survey shows that the process is very slow, and greatly retarded by browsing.

The economical evaluation showed that under longterm averages of timber prices, the revenues from timber production are low and mostly carried by the dominant cembran pine. As long as no economically efficient means of transporting harvested timber to roads exists the costs of harvesting and extraction exceed the income from timber sales. A sustainable revenue can only be achieved when the timber price for cembran pine remains high and when harvesting costs remain comparably low. The protection forest in Obergurgl is accessible by one road only in the valley. Expensive harvesting systems such as longdistance cableway logging or timber transport by helicopter can be used. Long-distance cableway logging requires the extraction of at least $1 \mathrm{~m}^{3}$ stemwood per 1-m length of the logging cable. Clear-cutting the forest would potentially yield the required timber quantity. However, in protection forests where approximately $70 \%$ of the stem volume needs to remain on-site, the extractable amount of timber is below economically feasible quantities. Under the encountered circumstances, government subsidies can cover the incurred economic loss of the forest owner. These subsidies are offered in order to ensure that silvicultural interventions for the sake of stand stability are conducted.

Our results showed that even modest harvests in 30year intervals lead to a reduction of the standing biomass stock. Such a strategy for forest management cannot be qualified as sustainable. The recommended management strategy for securing the overarching forest function of acting as a protection forest is therefore the extraction of small amounts of timber in long time intervals (Fig. 3). A viable argument in favor of forest management is the currently observed national trend towards unprecedented high tree biomass volumes (Büchsenmeister 2011; Amt der Tiroler Landesregierung 2011). The trend suggests that forests have been under-utilized in the past. The forest cover and stand density in mountain areas has already reached the desired level. The previous policy of further increasing the forest area is gradually replaced. Concepts are discussed how the present forest status can be maintained and how the annual timber increment can be extracted in a sustainable and economically viable manner. New management concepts are not yet sufficiently corroborated by experimental evidence. However, it is well established that high-quality timber can be processed in the local and regional value chain as an important element of the bio-economy, and low-quality wood products can contribute to bioenergy. Wood products are thereby substituting
Table 5 Revenue for each harvested cubic meter of wood $[€]$ and the interest rate for the invested money [\%], for the time span of 1960 to 2100 , expressed as return of investment

\begin{tabular}{lllll}
\hline & \multicolumn{2}{l}{ Revenue $\left[€ \mathrm{~m}^{-3}\right]$} & \multicolumn{2}{l}{ Rentability [\%] } \\
\cline { 2 - 5 } Management & Larch & Cembran pine & Larch & Cembran pine \\
\hline Extensive & $-11-11$ & $3-40$ & $0.23-0.94$ & $0.90-1.86$ \\
Intensive & $-12-11$ & $5-52$ & $0.38-1.56$ & $1.50-3.12$ \\
\hline
\end{tabular}


non-wood materials and are contributing to rural development (Amt der Tiroler Landesregierung 2011; Braun et al. 2016; Toscani and Sekot 2017; Werner et al. 2010).

In mountain regions, the economical aspect of forest management goes beyond the balance between harvesting costs and revenues from timber sales. The expenditures for silviculture in order to ensure the regeneration of forests ensure maintaining the desired stand structure that supports the provision of the central ecosystem services. Regionally, most important is the protection against natural hazards such as avalanches, flooding, and soil erosion. The incurred silvicultural costs are modest when compared to avoided costs for erecting and maintaining technical avalanche barriers. For partially subsidized silvicultural interventions in order to create an optimal forest structure, society receives sustainable protection against natural hazards. The mature cembran pine forests are also formative elements of the landscape in the Alps. They are structurally diverse and are habitats for many herbaceous plants and animals.

Upon zero forest management, the soil carbon pool increases (Fig. 4). The effect is slow and possibly transient. The uncertainty of carbon storage in the soil has been shown in many experiments and modeling exercises (Cox et al. 2000; Bradford et al. 2016; Ciais et al. 2008; Hiltbrunner et al. 2013; Hungate et al. 1996; Schimel et al. 2001; Schindlbacher et al. 2009). The climate scenarios A1B and $\mathrm{B} 1$ lead to different results. The lesser warming in the climate scenario B1 (Fig. 2) enables the ecosystem to maintain a higher soil carbon pool. Despite a smaller carbon input to the soil as consequence of the slightly lower productivity, the total soil carbon stock in the B1 scenario exceeds that of the warmer A1B scenario. This result emphasizes the strong impact of the decomposition rate of soil organic matter on the size of the soil carbon stock, as previously described (Cox et al. 2000; Karhu et al. 2010; Schindlbacher et al. 2008; Schindlbacher et al. 2009). However, the soil carbon stock does not increase indefinitely, even in ecosystems with a low frequency of disturbances (Bradford et al. 2016; Ciais et al. 2008). Even the extensive forest management with timber extractions in 50-year intervals leads to a decline in the soil carbon stock. The simulation model suggests that the low-productivity forest cannot replenish the carbon export due to harvesting via aboveground and belowground litterfall.

There are few field measurements of changes in the soil organic carbon pool in mountain forests over time. In an assessment of 24 sites in Germany, overall, a decrease in the soil carbon pool had been found and the decline has been attributed to climate change. The carbon loss was large on sites with calcareous bedrock, whereas sites on silicate showed a small increase in the soil carbon pool (Prietzel et al. 2016). The simulation for zero-management in our study shows a similar trend. In the two harvesting scenarios, the effect of reducing the flux of organic matter to the soil is much stronger than the climate effect.

A comparison of the three management scenarios suggests that zero management does not compromise the stability of the forest ecosystem. After 100 years, the stand density does not reach a level where internal competition would lead to an increase in tree mortality. Instead, the unmanaged forest is a strong and persistent carbon sink. Forest owners can therefore take advantage of eventually occurring favorable conditions on the timber market, but are not compelled to harvest. These harvesting opportunities are suitable for adaptations in the stand structure and the regeneration of the forest, mostly by creation of sufficiently large openings that the forest can regenerate. In the long run, a multi-layered, uneven-aged forest providing several ecosystem services simultaneously is ensured.

Our analysis suggests that forest management at the timberline is not necessarily calling for novel concepts. The existing strategies have been developed based on field observations at many sites and are highly effective. The overarching objective of creating stands of optimal stability is compatible with new challenges such as adverse climate change effects. The silvicultural strategies are in some regions only partially implemented. This is rather a consequence of diverging interests and not a lack of knowledge.

Acknowledgements This paper is an output of the projects (i) Management strategies to adapt Alpine Space forests to climate change risks (MANFRED), as part of the EU Interreg Alpine Space Programme, and (ii) EcoSoc Cuvée supported by the Austrian Academy of Sciences. Many thanks to C Corazzo, Richard Bauer, Dieter Stöhr, Ewald Pertlik and Frank Perzl on helpful information on forest operations, and to Klaus Dolschak and Beatriz Carrasco for field work.

Funding Information Open access funding provided by University of Vienna.

\section{Compliance with Ethical Standards}

Conflict of interest The authors declare that they have no conflict of interest.

Open Access This article is distributed under the terms of the Creative Commons Attribution 4.0 International License (http:// creativecommons.org/licenses/by/4.0/), which permits unrestricted use, distribution, and reproduction in any medium, provided you give appropriate credit to the original author(s) and the source, provide a link to the Creative Commons license, and indicate if changes were made.

\section{References}

Amt der Tiroler Landesregierung (ed) (2011) Waldstrategie 2020. Sterndruck GmbH, Fügen

Amt Tirol (2017) Forstlicher Förderkatalog FWP - Waldumweltmaßnahmen. Tiroler Landesforstdirektion. https://www.tirol.gv.at/file 
admin/themen/umwelt/wald/foerderung/downloads/Foerderkatalog_ Forst_1_2017_handout.pdf

Aulitzky H (1963) Grundlagen und Anwendung des vorläufigen WindSchnee-Ökogrammes. In: Ökologische Untersuchungen in der subalpinen Stufe - Teil 2, Mitteilungen der Forstlichen BundesVersuchsanstalt Mariabrunn, vol 60. Eigenverlag FBVA, chap F, pp 765-834

Bauhus J, Puettmann KJ, Kühne C (2013) Close-to-nature forest management in Europe. Compatible with managing forests as complex adaptive forest ecosystems?, Routledge, The Earthscan forest library, chap 9, pp 187-213

Bircher N, Cailleret M, Huber M, Bugmann H (2015) Empfindlichkeit typischer Schweizer Waldbestände auf den Klimawandel. Schweizerische Zeitschrift für Forstwesen 166:408-419. https://doi.org/10.3188/szf.2015.0408

Borsdorf A, Jandl R (2009) Global change and sustainable development in mountain regions: an introduction to the proceedings of the conference. In: Global change and sustainable development in mountain regions, vol 7. Innsbruck University Press

Bradford MA, Wieder WR, Bonan GB, Fierer N, Raymond PA, Crowther TW (2016) Managing uncertainty in soil carbon feedbacks to climate change. Nat Clim Change 6:751-758

Brang P, Spathelf P, Larsen JB, Bauhus J, Boncčina A, Chauvin C, Drössler L, García-Güemes C, Heiri C, Kerr G, Lexer MJ, Mason B, Mohren F, Mühlethaler U, Nocentini S, Svoboda M (2014) Suitability of close-to-nature silviculture for adapting temperate European forests to climate change. Forestry 87:492503. https://doi.org/10.1093/forestry/cpu018

Braun M, Fritz D, Braschel N, Büchsenmeister R, Freudenschuss A, Gschwantner T, Jandl R, Ledermann T, Neumann M, Pölz W, Schadauer K, Schmid C, Schwarzbauer P, Stern T, Weiss P (2016) A holistic assessment of green house gas dynamics from forests to the effects of wood products use in Austria. Carbon Management 7:271-283

Büchsenmeister R (2011) Waldinventur 2007/09: Betriebe und Bundesforste nutzen mehr als den Zuwachs. BFW-Praxisinformation 24:6-9

Bundesamt für Umwelt (BAFU) (ed) (2010) Wald und Wild Grundlagen für die Praxis Wissenschaftliche und methodische Grundlagen zum integralen Management von Reh. Rothirsch und ihrem Lebensraum, Gämse

Chinellato F, Faccoli M, Marini L, Battisti A (2013) Distribution of Norway spruce bark and wood-boring beetles along alpine elevational gradients. Agricultural and Forest Entomology. https://doi.org/10.1111/afe.12040

Ciais P, Schelhaas M, Zaehle S, Piao S, Cescatti A, Liski J, Luyssaert S, Le-Maire G, Schulze E, Bouriaud O, Freibauer A, Valentini R, Nabuurs G (2008) Carbon accumulation in European forests. Nat Geosci 1:425-429

Cox PM, Betts RA, Jones CD, Spall SA, Totterdell IJ (2000) Acceleration of global warming due to carbon-cycle feedbacks in a coupled climate model. Nature 408:184-187

Dale VH, Joyce LA, McNulty S, Neilson RP, Ayres MP, Flannigan MD, Hanson PJ, Irland LC, Lugo AE, Peterson CJ, Simberloff D, Swanson FJ, Stocks BJ, Wotton BM (2001) Climate change and forest disturbances. BioScience 51:723-734

Dolschak K, Jandl R, Ledermann T (2013) Coupling a forest growth model with a soil carbon simulator. InTech, chap 13

Eckmüllner O (2006) Allometric relations to estimate needle and branch mass of Norway spruce and Scots pine in Austria. Austrian J. Forest Sci. 123:7-16

Forest Act (1975) Bundesgesetz vom 3. Juli 1975, mit dem das Forstwesen geregelt wird (Forstgesetz 1975). https://www. ris.bka.gv.at/GeltendeFassung.wxe?Abfrage=Bundesnormen \& Gesetzesnummer=10010371, Accessed 03 May 2018
Frehner M, Wasser B, Schwitter R (2005) Nachhaltigkeit und Erfolgskontrolle im Schutzwald. Wegleitung für Pflegemassnahmen in Wäldern mit Schutzfunktion, Vollzug Umwelt. Bundesamt für Umwelt Wald und Landschaft. Bern, Schweiz

Fromme G (1961) Beschreibung des Stationsgebietes in ObergurglPoschach. Mitteilungen der Forstlichen Bundes-Versuchsanstalt Mariabrunn 59:53-68

Fuhrer J, Beniston M, Fischlin A, Frei C, Goyette S, Jasper K, Pfister $\mathrm{C}$ (2006) Climate risks and their impact on agriculture and forests in Switzerland. Clim Change 79:79-102

Gardiner B, Blennow K, Carnus JM, Fleischer P, Ingemarson F, Landmann G, Lindner M, Marzano M, Nicoll B, Orazio C, Peyron JL, Reviron MP, Schelhaas MJ, Schuck A, Spielmann M, Usbeck T (2010) Destructive storms in European forests: past and forthcoming impacts. EFI, Joensuu

Gardiner B, Schuck A, Schelhaas MJ, Orazio C, Blennow K, Nicoll B (eds) (2013) Living with storm damage to forests, what science can tell us, vol 3. EFI, Joensuu

Gewerkschaft PRO-GE (2014) Accessed 07 Oct 2014. Kollektivvertrag. http://www.kollektivvertrag.at/kv/forstarbeiter-privatwirtschaftarb/forstarbeiter-privatwirtschaft-rahmen/3536010

Grote V, Lackner H, Muhry F, Trapp M, Moser M (2003) Evaluation der Auswirkungen eines Zirbenholzumfeldes auf Kreislauf, Schlaf, Befinden und vegetative Regulation. Tech. rep., Joanneum Research. http://www.wilms.com/Hygiene/downloads/ zirbeinfo.pdf

Hanewinkel M, Cullmann DA, Schelhaas MJ, Nabuurs GJ, Zimmermann NE (2012) Climate change may cause severe loss in the economic value of European forest land. Nat Clim Change 3:203-207. https://doi.org/10.1038/NCLIMATE1687

Helmisaari HS, Makkonen K, Kellomäki S, Esko Valtonen E, Mälkönen E (2002) Below- and above-ground biomass, production and nitrogen use in Scots pine stands in eastern Finland. For Ecol Manage 165:317-326

Hiltbrunner D, Zimmermann S, Hagedorn F (2013) Afforestation with Norway spruce on a subalpine pasture alters carbon dynamics but only moderately affects soil carbon storage. Biogeochemistry 115:251-266. https://doi.org/10.1007/s10533-013-9832-6

Hungate BA, Jackson RB, Field CB, Chapin IIIFS (1996) Detecting changes in soil carbon in $\mathrm{CO}_{2}$ enrichment experiments. Plant Soil 187:135-145

IUSS Working Group WRB (2015) World reference base for soil resources 2014, update 2015, World Soil Resources Reports, vol No. 106, FAO

Jandl R, Price M (2011) Climate change. In: Price MF, Gratzer G, Duguma LA, Kohler T, Maselli D, Romeo R (eds) Mountain forests in a changing world-realizing values, addressing challenges. FAO, Rome, pp 62-63. chap 8

Jandl R, Schindlbacher A, Schüler S, Stöhr D (2012) Wald- und Waldgrenzenforschung in Obergurgl - Vergangenheit und Zukunft, Alpine Forschungsstelle Obergurgl, vol 2. Innsbruck University Press, chap 5, pp 125-145

Jandl $\mathrm{R}$ et al (2018) Carbon in biomass and soil at high elevation forest in Austria, Version 1. Vienna, Austria. CCCA Data Centre. [Dataset]. PID: https://hdl.handle.net/20.500.11756/0563079a

Karhu K, Fritze H, Hämälainen K, Vanhala P, Jungner H, Oinonen M, Sonninen E, Tuomi M, Spetz P, Kitunen V, Liski J (2010) Temperature sensitivity of soil carbon fractions in boreal forest soil. Ecology 91:370-376. https://doi.org/10.1890/09-0478.1. http://www.esajournals.org/doi/pdf/10.1890/09-0478.1

Kindermann G (2010) Eine klimasensitive Weiterentwicklung des Kreisflächenzuwachsmodells aus PrognAus. Centralblatt für das gesamte Forstwesen 127:147-178

Lal R, Pimentel D (2008) Soil erosion: a carbon sink or source? Science 319:1040-1041 
Land Tirol (2017) Access of webpage: 23 Nov 2017. Holzpreisauswertung. https://www.tirol.gv.at/umwelt/wald/holzmarkt/holzpreise/

Ledermann T (2002) Ein Einwuchsmodell aus den Daten der Österreichischen Waldinventur 1981-1996. Centralblatt für das gesamte Forstwesen 119:40-76

Ledermann T, Neumann M (2006) Biomass equations from data of old long-term experimental plots. Centralblatt für das gesamte Forstwesen 123:47-64

Ledermann T, Kindermann G, Gschwantner T (2017) National woody biomass projection systems based on forest inventory in Austria. In: Forest inventory-based projection systems for wood and biomass availability. Springer International, chap 6, pp 79-95

Lexer MJ, Jandl R, Nabernegg S, Bednar-Friedl B (2015) Forestry. In: Steininger KW, König M, Bednar-Friedl B, Kranzl L, Loibl W, Prettenthaler F (eds) Economic evaluation of climate change impacts-development of a cross-sectoral framework and results for Austria. Springer, pp 145-165. chap 9

Liski J, Tuomi M, Rasinmäki J (2009) Yasso07 user-interface manual. Tech. rep., Finnish Environment Institute. www.environment.fi/ syke/yasso

Marini L, Ayres MP, Battisti A, Faccoli M (2012) Climate affects severity and altitudinal distribution of outbreaks in an eruptive bark beetle. Climatic Change. https://doi.org/10.1007/s10584012-0463-z

Mayer H (1976) Gebirgswaldbau - Schutzwaldpflege. Gustav Fischer Verlag, Stuttgart

Möhring B, Püping U (2008) A concept for the calculation of financial losses when changing the forest management strategy. Forest Polic Econ 10:98-108

Monserud RA, Sterba H (1996) A basal area increment model for individual trees growing in even- and uneven-aged forest stands in Austria. For Ecol Manage 80:57-80. https://doi.org/10.1016/ 0378-1127(95)03638-5

Moser W, Peterson J (1981) Limits to Obergurgl's growth. Ambio 10:68-72

Nakicenovic N, Swart R (eds) (2000) IPCC emissions scenarios. Cambridge University Press, Cambridge

Netherer S, Matthews B, Katzensteiner K, Blackwell E, Henschke P, Hietz P, Pennerstorfer J, Rosner S, Kikuta S, Schume H, Schopf A (2015) Do water-limiting conditions predispose Norway spruce to bark beetle attack? N Phytol 205:1128-1141. https://doi.org/10.1111/nph.13166

Nicolussi K, Thurner A (2012) Wald- und Waldgrenzenforschung in Obergurgl - Vergangenheit und Zukunft, Alpine Forschungsstelle Obergurgl, vol 2. Innsbruck University Press, chap 6, pp 147-162

Offenthaler I, Hochbichler E (2006) Estimation of root biomass of Austrian forest tree species. Centralblatt für das gesamte Forstwesen 1/2:65-86

Österreichisches Kuratorium für Landtechnik (2017) Access of webpage: 23 Nov 2017. Gruppe 13: Maschinen und Geräte für die Forst und Holzwirtschaft. http://oekl.at/richtwerte-online/

Österreichische Waldinventur (2016) http://www.waldinventur.at

Pluess A, Brang P, Augustin S (eds) (2016) Wald im Klimawandel. Haupt Verlag, Bern

Pretzsch H, Biber P, Schütze G, Bielak K (2013) Changes of forest stand dynamics in Europe. Facts from long-term observational plots and their relevance for forest ecology and management. For Ecol Manage 315:65-77

Price MF, Gratzer G, Duguma LA, Kohler T, Maselli D, Romeo R (2011) Mountain forests in a changing world-realizing values, addressing challenges. Tech rep., FAO/MPS and SDC, Rome

Prietzel J, Zimmermann L, Schubert A, Christophel D (2016) Organic matter losses in german alps forest soils since the 1970s most likely caused by warming. Nat Geosci 9:543-548

Rantakari M, Lehtonen A, Linkosalo T, Tuomi M, Tamminen P, Heikkinen J, Liski J, Mäkipää R, Ilvesniemi H, Sievänen
R (2012) The Yasso07 soil carbon model—testing against repeated soil carbon inventory. For Ecol Manage 286:137-147. https://doi.org/10.1016/j.foreco.2012.08.041

Reichstein M, Bahn M, Ciais P, Frank D, Mahecha MD, Seneviratne SI, Zscheischler J, Beer C, Buchmann N, Frank DC, Papale D, Rammig A, Smith P, Thonicke K, van der Velde M, Vicca S, Walz A, Wattenbach M (2013) Climate extremes and the carbon cycle. Nature 500:287-295

Reimoser F (2003) Steering the impacts of ungulates on temperate forests. J Nat Conserv 10:243-252

Rogelj J, Meinshausen M, Knutti R (2012) Global warming under old and new scenarios using IPCC climate sensitivity range estimates. Nat Clim Change 2:248-253. https://doi.org/10.1038/ NCLIMATE1385

Rössler G (2015) Wuchsleistungsvergleich zwischen Vor- und Folgebeständen langjähriger Fichten-Dauerversuchsflächen. BFWDokumentation 19:1-199

Schimel D, House J, Hibbard K, Bousquet P, Ciais P, Peylin P, Braswell B, Apps M, Baker D, Bondeau A, Canadell J, Churkina G, Cramer W, Denning A, Field C, Friedlingstein P, Goodale C, Heimann M, Houghton R, Melillo J, Moore B III, Murdiyarso D, Noble I, Pacala S, Prentice I, Raupach M, Rayner P, Scholes R, Steffen W, Wirth C (2001) Recent patterns and mechanisms of carbon exchange by terrestrial ecosystems. Nature 414:169172

Schindlbacher A, Zechmeister-Boltenstern S, Kitzler B, Jandl R (2008) Experimental forest soil warming: response of autotrophic and heterotrophic soil respiration to a short-term $10{ }^{\circ} \mathrm{C}$ temperature rise. Plant Soil 303:323-330. https://doi.org/10.1007/s11104007-9511-2

Schindlbacher A, Zechmeister-Boltenstern S, Jandl R (2009) Carbon losses due to soil warming: do autotrophic and heterotrophic soil respiration respond equally? Glob Chang Biol 15:901-913. https://doi.org/10.1111/j.1365-2486.2008.01757.x

Seidl R, Thom D, Kautz M, Martin-Benito D, Peltoniemi M, Vacchiano G, Wild J, Ascoli D, Petr M, Honkaniemi J, Lexer MJ, Trotsiuk V, Mairota P, Svoboda M, Fabrika M, Nagel TA, Reyer CPO (2017) Forest disturbances under climate change. Nat Clim Change 7:395-402

Senn J, Schönenberger W (2001) Zwanzig Jahre Versuchsaufforstung Stillberg: Überleben und Wachstum einer subalpinen Aufforstung in Abhängigkeit vom Standort. Schweizer Zeitschrift für Forstwesen 152:226-246

Tasser E, Walde J, Tappeiner U, Teutsch A, Noggler W (2007) Landuse changes and natural reforestation in the eastern central alps. Agric Ecosyst Environ 118:115-129

Thom D, Rammer W, Seidl R (2017) Disturbances catalyze the adaptation of forest ecosystems to changing climate conditions. Glob Chang Biol 23:269-282. https://doi.org/10.1111/gcb.13506

Toscani P, Sekot W (2017) Assessing the economic situation of smallscale farm forestry in mountain regions: a case study in Austria. Mt Res Dev 37:271-280

Trumbore S, Brando P, Hartmann H (2015) Forest health and global change. Science 349:814-818

Tuomi M, Thum T, Järvinen H, Fronzek S, Berg B, Harmon M, Trofymov J, Sevanto S, Liski J (2008) Global patterns of leaf litter decomposition. Tech. rep., Finnish Environment Institute

Tuomi M, Thum T, Järvinen H, Fronzek S, Berg B, Harmon M, Trofymow J, Sevanto S, Liski J (2009) Leaf litter decompositionestimates of global variability based on Yasso07 model. Ecol Model 220:3362-3371

Turner H (1961) Die Niederschlags- und Schneeverhältnisse. In: Ökologische Untersuchungen in der subalpinen Stufe - Teil 1, Mitteilungen der Forstlichen Bundes-Versuchsanstalt Mariabrunn, vol 59, Eigenverlag FBVA, chap 8, pp 265-315 
WAMOD (2010) Auswirkungen des Klimawandels auf Österreichs Wälder - Entwicklung und vergleichende Evaluierung unterschiedlicher Prognosemodelle (WAMOD). Endbericht, Institut für Waldbau, Institut für Waldwachstumsforschung (BOKU); Institut für Waldwachstum und Waldbau Institut für Waldinventur. BFW, Wien

Werner F, Taverna R, Hofer P, Thürig E, Kaufmann E (2010) National and global greenhouse gas dynamics of different forest management and wood use scenarios: a model-based assessment.
Environ Sci Polic 13:72-85. https://doi.org/10.1016/j.envsci.2009. 10.004

Wirth C, Schulze E, Schwalbe G, Tomcyk S, Weber G, Weller E (2004) Dynamik der Kohlenstoffvorräte in den Wäldern Thüringens, Mitteilungen Thüringer Landesanstalt für Wald, Jagd und Fischerei, vol 23 Thüringer Ministerium für Landwirtschaft. Naturschutz und Umwelt, Gotha

Zimmermann NE, Gebetsroither E, Züger J, Schmatz D, Psomas A (2013) Future climate of the European alps. InTech, chap 3

\section{Affiliations}

\section{Nathalia Jandl ${ }^{1}$ - Robert Jandl ${ }^{2}$ - Andreas Schindlbacher ${ }^{2}$}

Nathalia Jandl

nathalia.jandl@univie.ac.at

Robert Jandl

robert.jandl@bfw.gv.at

Andreas Schindlbacher

andreas.schindlbacher@bfw.gv.at

1 Department of Ecogenomics and Systems Biology,

University Vienna, Althanstrasse 14, 1090 Vienna, Austria

2 Austrian Research Center for Forests, Seckendorff-Gudent Weg 8, 1131 Vienna, Austria 